\title{
Assessment of Selected Properties of Treated Tool Surfaces Examined to Incre- ase Tool Life Time
}

\author{
Miroslava Ťavodová, Richard Hnilica \\ Faculty of Environmental and Manufacturing Technology, Technical University in Zvolen, Študentská $26,96053$. \\ Slovak Republic, E-mail: tavodova@tuzvo.sk, hnilica@tuzvo.sk
}

The article deals with the evaluation of interactions between abrasive particles and treated sample surfaces. It represents a summary of the knowledge gained from research the wear of tools for crushing unwanted growths. Samples of materials were tested under laboratory conditions. The hardness of HRC and HV10 was evaluated in the experiment, abrasive wear rate, assessed according to standard GOST 23.208-79. The depth of the track under test disc by using silicon abrasive particles was also evaluated. Furthermore, the hardness coefficient $K_{T}$ relative to the base material of the tool - $16 \mathrm{MnCr} 5$ steel and the hardness of abrasive were determined. By comparing the measured and calculated values the heat treatment procedures and hardfacing materials were assessment. By comparing the measured and calculated values the heat treatment procedures and hardfacing materials were assessment, which are expected to provide an increase the abrasion resistance towards to an abrasive, heterogeneous working environment in operation.

Keywords: microploughing, microcutting, abrasive wear, heat treatment, hardfacing materials.

\section{Introduction}

Tools used in forestry technology are subject to abrasive wear. It is an intensive degradation process, which is caused mostly by the effect of hard, mainly mineral particles. The mechanism of abrasive wear is related to the surface - hard particle interaction. Analysis of the abrasive wear mechanism on exposed parts will help in designing methods for increasing their service life in service [1]. An essential characteristic of the wear process is the conditions under which the wear occurs. Without this specification, the wear process cannot be analysed. Operating conditions represent the whole set of often varied variables, the change of which leads to a change in intensity or even to change mechanism of abrasive wear. There are several methods and procedures to increase the wear resistance of tools. By selecting those that will change the structure more resistant to abrasive wear of the tool body, we can extend its use in service. This creates a presumption to increase its service life time. This will reduce costs for forest operators [2].

\section{Materials and methods}

As written by the authors [3,4], significant factors determining the resistance to abrasive wear include the hardness, size, shape and intensity of the acting of particles. Furthermore, there are a number of hard phases and their distribution in the base metal matrix. With increasing hardness of hard structural components (carbides, borides, etc.) and their increasing proportion in the structure, wear resistance increases. When processing unwanted growths, in a heterogeneous working environment, in addition to wood mass, have a significant proportion rocks and minerals of varying hardness (quartzite, quartz, ferrous and calcareous sandstones, etc.), which are irregularly occurring on the terrain surface $[1,5]$.

Abrasive wear is defined as the separation of particles from a functional surface by the hard and rough surface of the second body. It is an intensive degradation process, mostly due to the effect of hard, mainly mineral particles. The particles of material are separated and moved.

The authors $[3,6,7]$ have defined four types of interaction between abrasive particles and worn material. It is a general model of abrasive wear. Typical situations that occur during abrasive wear:

- microploughing,

- microcutting,

- microcutting connected with fatigue fracture,

- microcutting connected with microcracks.

In ideally of microploughing, the moving of one abrasive particle does not result in any separation of material from the surface. The material is continuously moved to the sides to form peaks adjacent to the already formed groove (Fig.1a). Over time, there may be a loss of volume due to additional the impact other abrasive particles or repetitive action of a single particle $[6,8]$. 


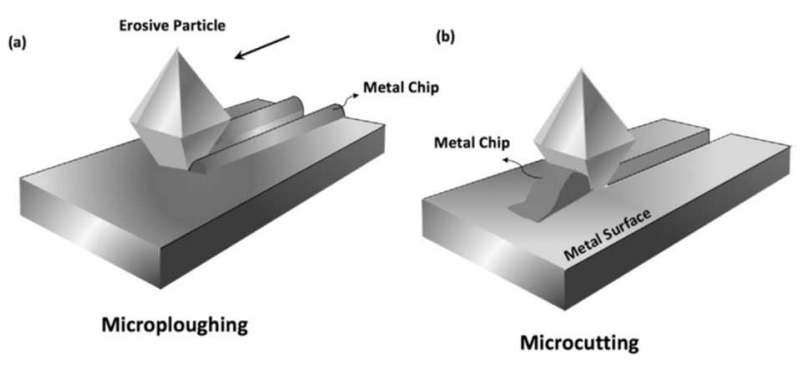

Fig. 1 Scheme of mechanism: a, microploughing - ductile material; b. microcutting - brittle material [6]

Microploughing and microcutting are the dominant processes on ductile materials. Microcutting, which is associated with the formation of microcracks, occurs more with brittle materials (Fig. 1 a, b). In the formation of microplough, there is considerable plastic deformation, with transverse micro-cracks forming at the bottom of the cracks, which are the initiative of further disruption.
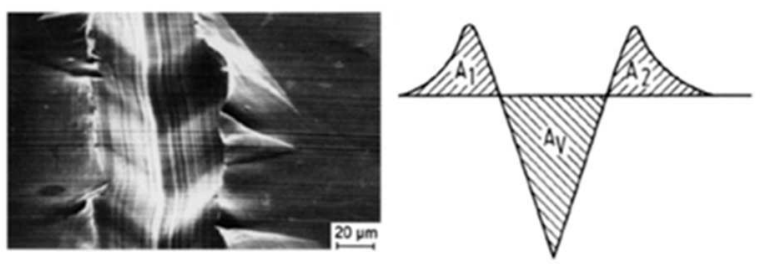

Fig. 2Microcutting on surface of the material [7]

The result of microcutting is a loss of volume in the form of a chip that is equal to the volume of the grooves formed (Fig.2). Microcracks, which are created by the abrasive particles cause highly concentrated stresses, especially on the surface of brittle materials. In this case, the wear is high due to the formation and spread of cracks [6,7]. A schematic interpretation of the abrasive wear stages is shown in Fig. 3.

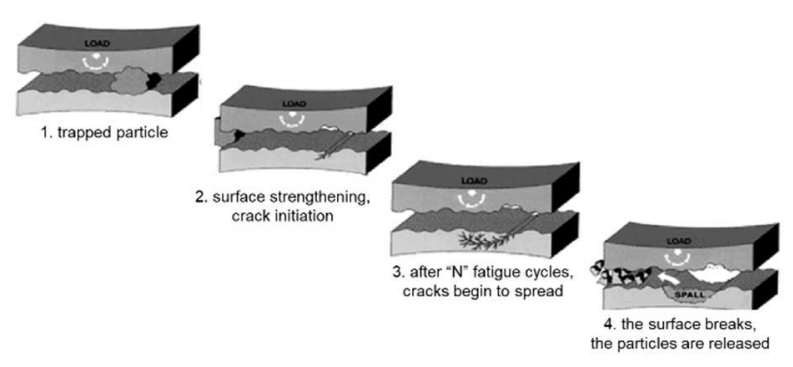

Fig. 3 Stages of abrasive wear

Up to now, there is no consistent view of the most suitable type of structure in terms of abrasion resistance [9]. Some authors consider the most suitable austenitic-carbide structure - suitable for abrasion conditions at high specific pressures and the presence of impacts. Others, in turn consider a martensitic-carbide structure - for low-stress abrasion conditions. These divergent views result from the diversity of the abrasive wear process and the wide range of actual operating conditions $[7,9,10]$.

When evaluating abrasive wear resistant metal materials, two types of structures are encountered. These are heterogeneous structures, consisting of several structural components (they consist of combinations of ferrite, perlite, carbides, borides, carboborides and others.) and homogeneous structures, which consist of a single structural component (e.g. austenitic) $[9,11]$.

These differences result from different wear conditions. In the case of abrasive wear, two crucial stages must be distinguished $[1,9,12]$ :

- the process of indenting the abrasive into the surface, where hardness is the decisive factor,

- the surface disruption process, where interatomic bonds and the strength of the bonding between the structural constituents at the grain boundaries play a decisive role.

As already mentioned in the article and according the authors $[5,9,13]$ too, in the formation of microcracks, there is considerable plastic deformation, with transverse micro-cracks forming at the bottom of the cracks, which are the initiative of further disruption. For this reason, steel with a ferritic structure has the lowest resistance to abrasive wear. The ferritic-pearlitic steel has a slightly higher wear resistance. The presence of martensite in the steel structure increases by more than three times the wear resistance compared to ferritic-pearlitic steel. The addition of carbides (the high degree of alloying) increases the hardness of the steels, but does not always guarantee the best wear resistance. For example, a ferritic-carbidic steel at 60 HRC hardness has approximately the same wear resistance as a steel with sorbite structure with a hardness of 45HRC. In the combined impact of abrasion and impacts, relatively soft but tough materials are sometimes used. These are austenitic manganese steels, martensitic alloys and high alloy steels, air hardenable $[7,14]$.

\section{Experiment}

The research stimulated by practice requirements was aimed at addressing the problem of low tool life time for crushing unwanted increases, which in a heterogeneous environment, were quickly subject to wear. Therefore, to increase the life time of these tools, the procedures and methods of adjusting the body of tool have been specified - by heat and chemicalheat treatment and weld overlaying - application of hard facing materials. We assumed that a tool with a more durable structure and better mechanical properties could better withstand adverse operating conditions. As reported in articles and research works $[1,2,5,15,18]$, where research was gradually published, 
by analyzing the mechanical properties of the tool material for crushing unwanted growths - hardness, microhardness, impact toughness, abrasive wear resistance of the material, with evaluation of trace depth - we obtained basic data on the tool as well as on the working environment. The tool is a forging made of construct low-alloy cemented chrome-manganese

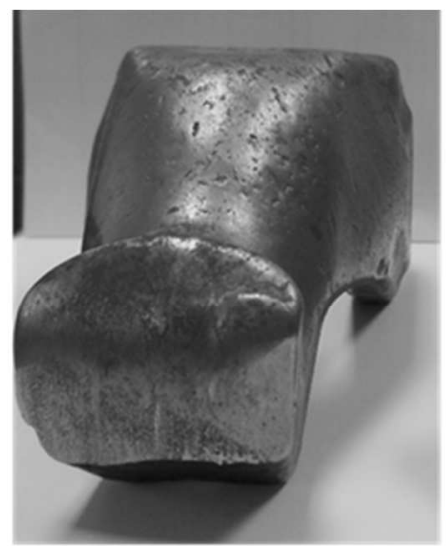

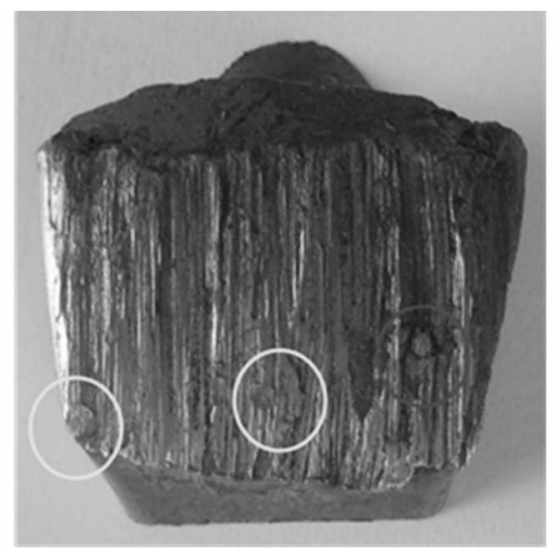

a. steel class 14 220, designation according to DIN $16 \mathrm{MnCr} 5$, Wr. Nr. 1.7131. It has a ferritic-pearlitic body structure in a state without heat treatment and thus, after loss of wolfram-carbide (WC) tips, unsuitable for working environment in which it is deployed (Fig. 4).

Fig. 4 Damaged tool - upper part of the tool body after loss of WC tips a. Grooving by hard elements; $b$. Exposed areas on the tool

The Initial analyses, published in $[1,5,17]$, were identified the mechanisms of wear of the back surface of the instrument after loss of WC tips. This is the abrasive impacting of hard rock particles (abrasion) occurring in the stand as well as the action of wood particles produced during its crushing (they are but less significant). In a heterogeneous environment, the tools are also subjected to dynamic loads and impacts. When rotating, the cylinder of adapter of tractor ( $\mathrm{n}=$ 1000 to $1200 \mathrm{rpm}$ ) is a cyclic loaded.

The state on the surface of the material with groove sensed by SEM is shown in Fig. 5. These analysis, performed by electron microscopy, can provide a better picture and overview of the situation associated with plastic deformation of surface of tool. [22]. It shows a significant plastic deformation of the material. If the surface is damaged by abrasive wear may remain at the bottom of the groove the defragmented material.

To achieve such structures that would increase the resistance to abrasive wear of tools and thereby increase their service life in service, as well as the theoretical knowledge presented $[15,16,17]$, the following procedures and methods were selected and evaluated on samples.

- technological processes of heat treatment:

Sample No.1 - hardening and tempering;

Sample No.2 - chemical-heat treatment - case-hardening.

- weld overlaying - application of hardfacing materials, where following welding materials have been selected:
Sample No.3 - electrode E520 RB - high content of chromium and carbon, forms ledeburitic structure with presence of chromium carbides;

Sample No.4 - filled rod for manual welding by flame RD 571 - welding of tungsten-carbide layers, special weld material consisting of WC carbides in a steel matrix;

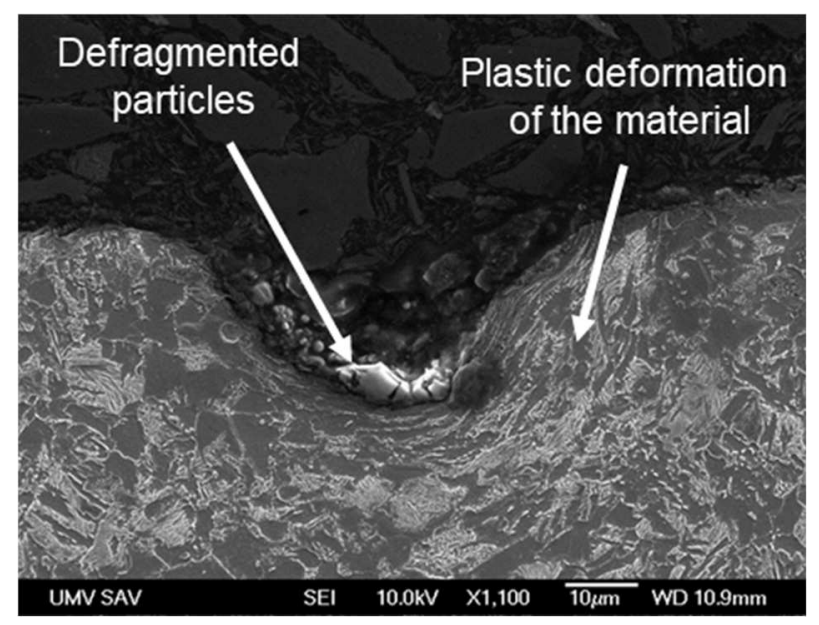

Fig. 5 The plastic deformation of the material and the defragmented particles at the bottom of the groove

Sample No.5 - weld wire LNM 420FM - creates layers with ferritic-martensitic structure, which are highly resistant to abrasion, shock and corrosion;

Sample No.6 - electrode E DUR600 - ledeburic structure of weld deposit, low content of carbon and chromium;

Sample No.7 - electrode WEARTRODE 62 (OK 84.84 ) - weld deposit metal with high content of fine 
carbides in martensitic matrix.

A sample from a worn tool for crushing unwanted growths has designation - Sample No.0 and is considered a standard (etalon).
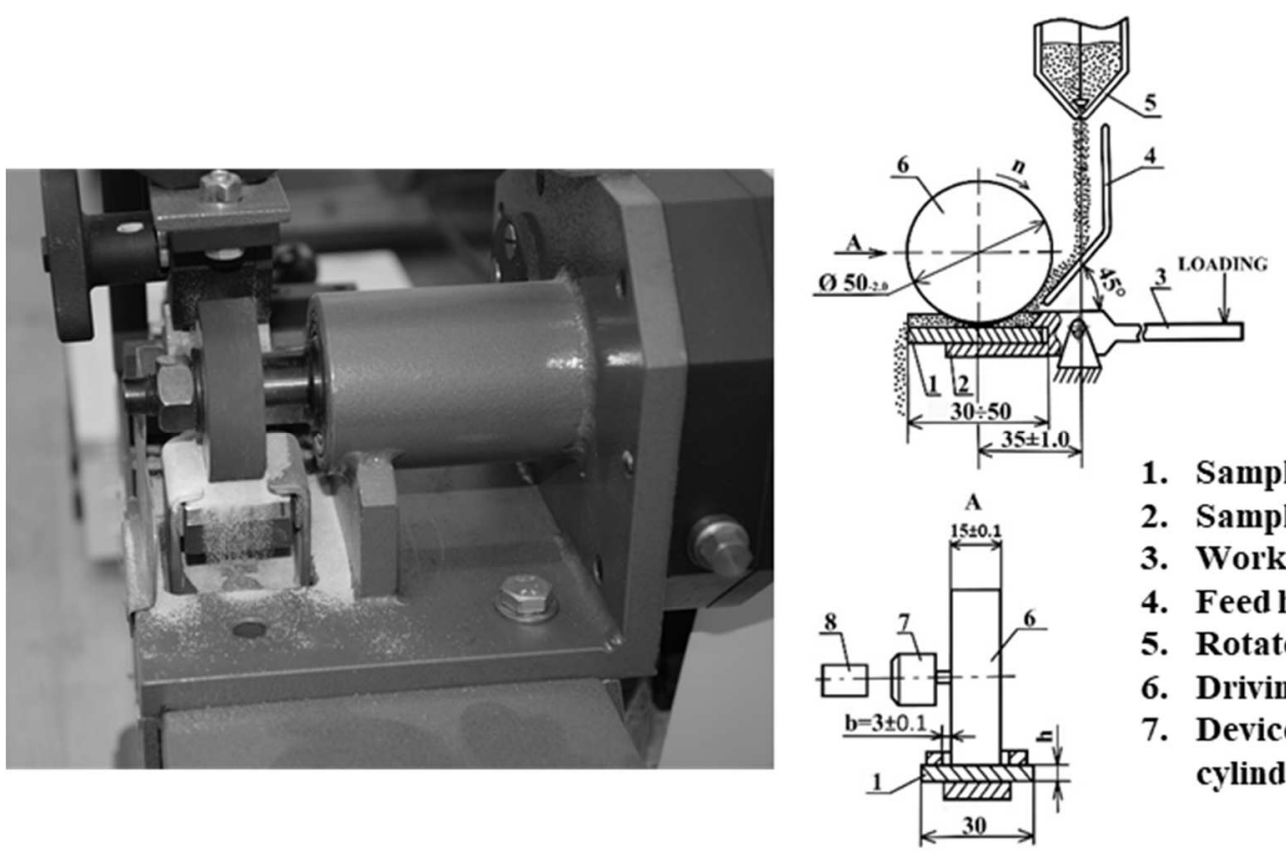

1. Sample

2. Sample holder

3. Working lever

4. Feed hopper

5. Rotate rubber cylinder

6. Driving gear

7. Device for checking the total cylinder speed during the test

Fig. 6 Test equipment for testing wear resistance testing of materials by friction against loosely fixed abrasive particles and a scheme with the description

The following tests and measurements have been carried out to determine the interactions between the abrasive particles and the surface of the heat treated and hard facing material samples:

- HV10 and HRC hardness measurements;

- wear resistance testing of materials by friction against loosely fixed abrasive particle;

- tracking of the profile and depth of the track of disc on the sample by a confocal microscope.

Vickers hardness was measured on the Vickers hardness tester 432SVD. Load duration $\mathrm{t}=15 \mathrm{~s}$, load force $\mathrm{F}=98.07 \mathrm{~N}$. The Rockwell measurement was performed on a universal hardness tester UH250, load force $\mathrm{F}=1471 \mathrm{~N}$.

Sample preparation and testing of material resistance to wear was carried out according to Russian standard GOST 23.208-79. Wear resistance testing of materials by friction against loosely fixed abrasive particles [19]. It is a standard from a group of standards Ensuring of wear resistance of products. The principle of the method is to compare the loss of the tested material and the loss of the standard material under the same test conditions. The test facility and scheme with description is shown in Figure 6. The silica sand OTTAWA with a grain size of $0.1-0.3 \mathrm{~mm}$ and with content $\mathrm{SiO}_{2}$ of over $96 \%$ was used for testing. It is characterized by high mechanical resistance, uniform grain distribution and high chemical resistance. The hardness corresponds to the seventh degree of mineral hardness according the Mohs. The seventh degree of hardness corresponds approximately to the hardness values according to the hardness assessment methods used in the technique, namely $450 \mathrm{HB}, 500 \mathrm{HV}$ and 54HRC.

The profile and also the trace depth $\mathrm{P}_{\mathrm{t}}[\mu \mathrm{m}]$ on the sample after the abrasion wear test was observed with a confocal microscope Neox Plu (Sensofar company) used for accurate 3D surface scanning.

\section{Results}

Evaluation of the results of laboratory tests on samples should give us a basic picture of the suitability or unsuitability of selected procedures and methods in terms of their mechanical properties.

One indicator of abrasion resistance is the coefficient $\psi_{\mathrm{h}}$, determined from the weight loss $\mathrm{W}_{\mathrm{h}}$. The graphs in Fig. 7 show the course and increase of $\mathrm{W}_{\mathrm{h}}$ and $\psi_{\mathrm{h}}$ during the abrasion wear test as a function of the distance travelled. As can be seen, samples No. 1, 2,5 and 6 had a large weight loss and hence a low coefficient $\psi_{\mathrm{h}}$, close to the values of the standard (Sample No.0). This is related to the mechanical properties, especially the hardness of the individual materials tested. 

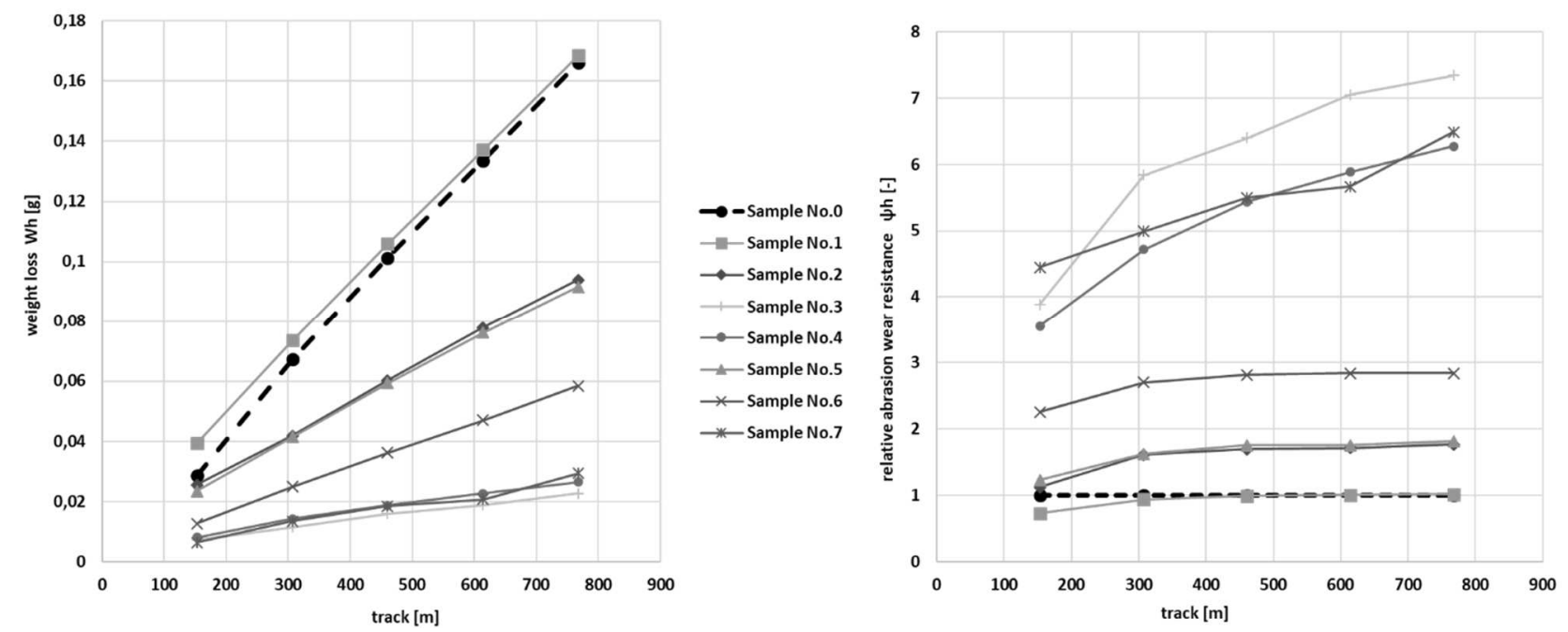

Fig. 7 The course of $W_{b}$ and $\psi_{b}$ depending on the travelled track

To compare the $\psi_{\mathrm{h}}$ of the standard and the values obtained from the abrasion resistance tests, a graph was constructed (Fig. 8) in which the samples are arranged according to the lowest coefficient achieved.

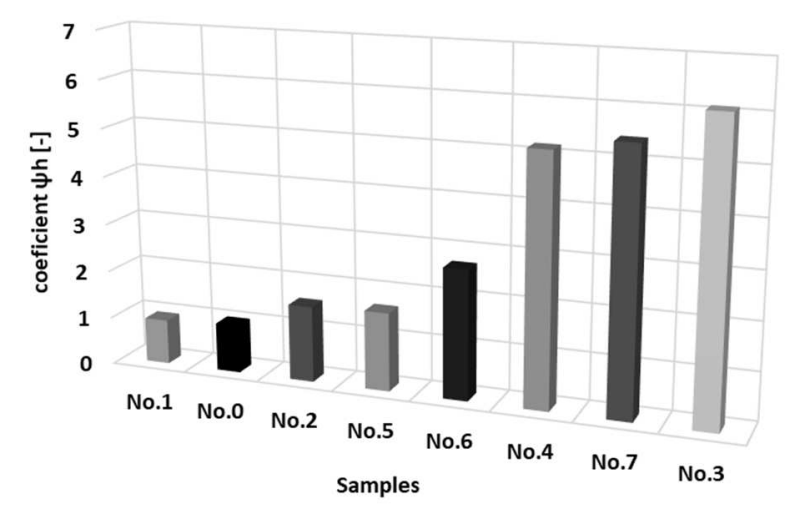

Fig. 8 Sorting the samples by coefficient $\psi h[-]$

The lowest wear resistance, quantify by the coefficient $\psi \mathrm{h}$, was find on the heat treated sample, albeit only by a very small value from the standard $16 \mathrm{MnCr} 5$ steel $(14220)$, i.e. Sample No.0. Heat treatment by hardening and tempering has proven to be unsuitable in laboratory tests from this point of view. Neither the chemical-thermal treatment (Sample No.2) nor the LNM 420FM (Sample No.5) reached twice the value of the coefficient $\psi_{h}$ of the standard (Sample No.0). The highest wear resistance was achieved Sample No.3 - electrode E520 RB.

By evaluating the hardness coefficient $\mathrm{K}_{\mathrm{T}}$, which represents the ratio of the hardness of the abrasive to the hardness of the evaluated surface, we can determine which of the materials would best withstand the abrasive load. Based on the evaluation, whose graphical representation is in the graph (Fig. 9), we can conclude that weld overlaying materials have a higher coefficient $K_{T}$. A value higher than $K_{T}=1$ did not reach on the Sample No.1, whose modification of the structure proved again unsuitable in laboratory conditions.

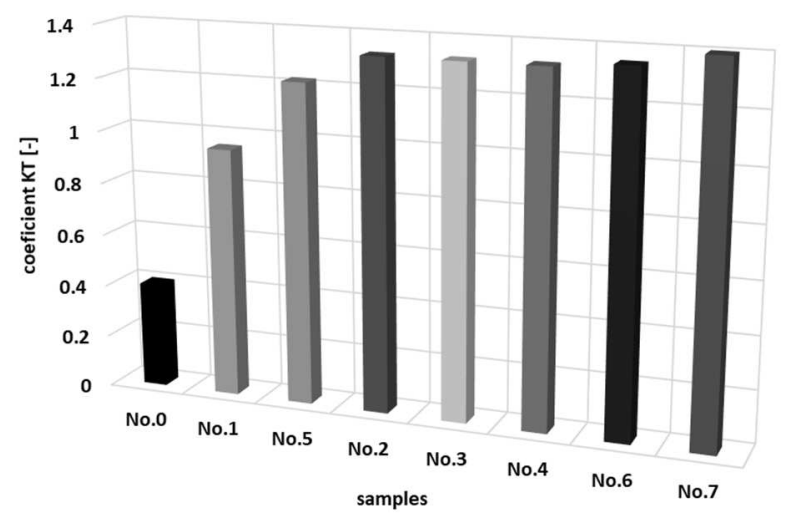

Fig.9 Sorting the samples according to hardness coefficient $K_{T}$ [-]

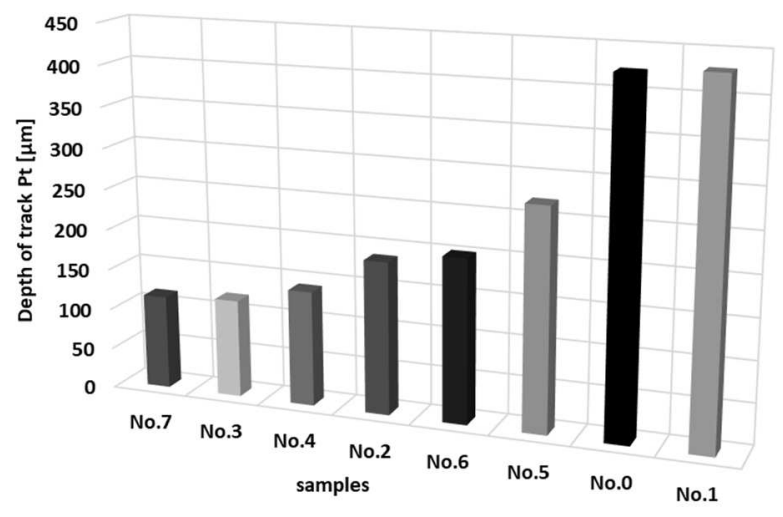

Fig. 10 Sorting the samples according to $P_{t}[u m]$

In the input analysis on samples from the untreated instrument by FEM and light microscopy as well as SEM, a wear depth of $0.20 \mathrm{~mm}$ was defined, resulting from cyclically repeating subsurface reinforcement of the material by plastic deformation under the influence of the identified working environment factors [1,5]. The profile and depth of the $P_{t}$ trace on the 
samples after the abrasive wear test, was examined by the confocal microscope. Parameter $P_{t}$ we determined as a parameter expressing the depth of removal on the exposed area.

Based on the obtained values a graph was constructed (Fig. 10), where the samples are sorted according to the depth of the trace $\mathrm{P}_{\mathrm{t}}$. From the graph we can see that the traces on Samples No.7, 3, 4, 2 and 6 were recorded to a depth of $200 \mu \mathrm{m}=0.2 \mathrm{~mm}$. Based on the above, it can be stated that it is the depth that represents the addition to the material. This would take on the role of a protective layer that retains the wear mechanisms causing a loss of tool material.

The HRC and HV10 methods were used to measure the hardness of the treated surfaces on the samples. The HRC value is more significant and valid, because it is stated in the evaluation of hardness after heat treatment, resp. it is cited by manufacturers of hardfacing materials. Again the lowest values compared to the standard had Sample No.1 and the highest Sample No.7 - electrode Weartrode 62. However, up to four samples were achieved a hardness of $60 \mathrm{HRC}$. This corresponds to the values given in the technical data sheets of the hardfacing materials. HRC is the most balanced value that has been assessed. Strongly corresponds to $\mathrm{K}_{\mathrm{T}}$ values. Sorting of samples according to achieved hardness of HV10 and HRC on samples after application of the proposed methods compared to the hardness of the standard is in Fig. 11.

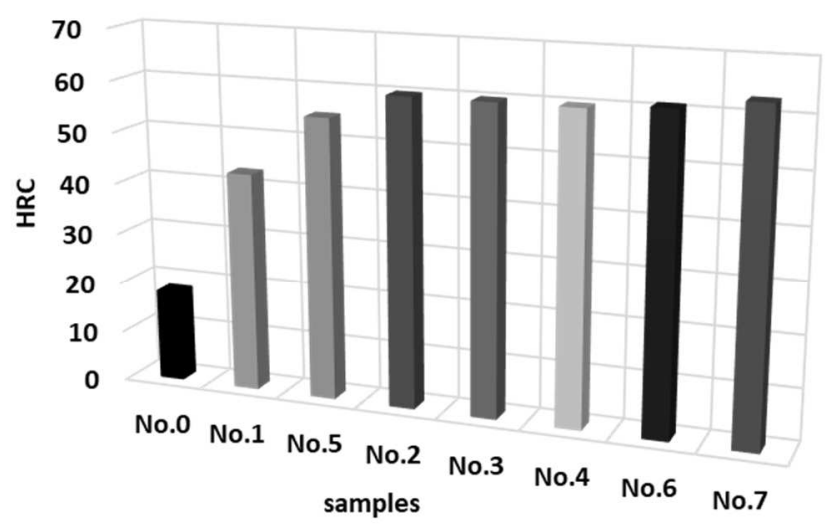

Fig. 11 Sorting samples according to HRC and HV10 hardness

We can say that the order of samples according to the hardness values of HV10, measured to obtain more accurate hardness values of the structural samples, are comparable to the HRC measurement results. Sample No.4 and Sample No.7 have the highest hardness. We assume that this is due to the presence of carbides of elements $\left(\mathrm{C}, \mathrm{Cr}, \mathrm{Ti}, \mathrm{W}_{2} \mathrm{C}\right)$ in the ferritic base. Table 1 was created for a more transparent evaluation of the HRC and HV10 hardness increases.

Tab. 1 Increase of hardness values HRC and HV10 - comparison

\begin{tabular}{|c|c|c|c|c|c|c|c|c|}
\hline Hardness & $\begin{array}{c}\text { Sample } \\
\text { No.0 }\end{array}$ & $\begin{array}{c}\text { Sample } \\
\text { No.1 }\end{array}$ & $\begin{array}{c}\text { Sample } \\
\text { No.2 }\end{array}$ & $\begin{array}{c}\text { Sample } \\
\text { No.3 }\end{array}$ & $\begin{array}{c}\text { Sample } \\
\text { No.4 }\end{array}$ & $\begin{array}{c}\text { Sample } \\
\text { No.5 }\end{array}$ & $\begin{array}{c}\text { Sample } \\
\text { No.6 }\end{array}$ & $\begin{array}{c}\text { Sample } \\
\text { No.7 }\end{array}$ \\
\hline HRC & 18 & 43 & 60 & 60 & 60 & 55 & 61 & 63 \\
\hline Increase & - & $2.39 \mathrm{x}$ & $3.30 \mathrm{x}$ & $3.30 \mathrm{x}$ & $3.30 \mathrm{x}$ & $3.05 \mathrm{x}$ & $3.30 \mathrm{x}$ & $3.05 \mathrm{x}$ \\
\hline HV10 & 225 & 337 & 627 & 625 & 825 & 620 & 720 & 800 \\
\hline Increase & - & $1.50 \mathrm{x}$ & $2.8 \mathrm{x}$ & $2.8 \mathrm{x}$ & $3.78 \mathrm{x}$ & $2.76 \mathrm{x}$ & $3.2 \mathrm{x}$ & $3.56 \mathrm{x}$ \\
\hline
\end{tabular}

By evaluating the suitability of the selected methods for application to the tools for crushing unwanted growths, it can be concluded that none of the heat treatment technological processes for increasing the abrasive wear resistance in laboratory tests has achieved the expected results.

Based on the results of laboratory tests and measuring, we assume that the best results in operation will be achieved by surfacing materials:

- electrode E 520 RB;

- wire LMN 420FM;

- electrode E DUR 600.
Several authors $[3,4,6,7,12,16,20,21]$ have theoretically described in their research papers the influence of factors on the abrasive wear of materials. These are the influences of mechanical properties, structure, chemical elements, the effect of abrasives and conditions of services. Their impact on increasing tool life, by changing the structure of exposed parts, was evaluated through graphs. The calculated and measured coefficients and values obtained from the results of tests and sample tests were compared. It can be stated that the results obtained in the laboratory experiment largely coincided with those of works of the authors. 


\section{Conclusion}

The paper presents a summary of partial results of a longer-term research of procedures and methods that would, by their application, achieve a change in the body structure of the tool for crushing unwanted growths and thus increase their service life in operation. In the selection of technological processes as well as hardfacing materials, which ensure the reduction of the effects of abrasive wear, we have followed the theoretical knowledge and experimental results published in the literature [23]. The selection was consulted with experts with a wealth of practical experience.

The knowledge gained from the results of laboratory experiments will be fully applied in practice. Feedback from the user of the tools, which will allow us to continue research on their field equipment, will determine whether the selected methods and methods will ensure a longer tool life and thus verify the validity of the proposed innovations.

\section{Acknowledgment}

„This work was supported by the Slovak Research and Development Agency under the contract No. $A P V V$-16-0194“.

\section{References}

[1] ŤAVODOVÁ, M. et al. (2018). Deformation of exposed parts tool for crushing of undesirable advance growths In: Acta technologica agriculturae, Vol. 21, No. 4, pp. 169-176.

[2] ŤAVODOVÁ, M. et al. (2018). The possibility of increasing the wearing resistance of mulcher tools In: Acta technologica agriculturae, Vol. 21, No. 2, pp. 87-93.

[3] ZUM GAHR, K.H. (1998). Wear by hard particles. In: Tribology International, Vol. 31, No. 10, pp. 587-596.

[4] SUCHÁNEK, J., KUKLÍK, V., ZDRAVECKÁ, E. (2007). Abrazivini opotrébeni materiálio. Praha ČVUT, 2007. 162s. ISBN 97880-01-03659-4.

[5] FALAT, L., DZUPON, M., TAVODOVA, M., HNILICA, R., LUPTACIKOVA, V., CIRIPOVA, L. HOMOLOVA, V. AND DURISOVA, K. (2019). Microstructure and Abrasive Wear Resistance of Various Alloy Hardfacings for Application on Heavy-Duty Chipper Tools in Forestry Shredding and Mulching Operations, In: Materials, July 2019 12(13): [online]. 04.02.2020. Available from https://www.researchgate.net/publication/334380057_Microstructure_and_Abra-
sive_Wear_Resistanceof_Various_Alloy_Hardfacings_for_Application_on_HeavyDuty_Chipper_Tools_in_Forestry_Shredding_and_Mulching_Operations. DOI: $10.3390 / \mathrm{ma1} 2132212$

[6] JAVAHERI, V. [et al.]. (2018) Slurry erosion of steel - Review of tests, mechanisms and materials In: Wear, 408-409 (2018) 248-273.

[7] CHOTĚBORSKÝ, R. et al. (2009). Effect of abrasive particle size on abrasive wear of hardfacing alloys. In: RES. AGR. ENG., 55, (3): 101-113 [online]. cit.19.05.2019. Available from https://www.agriculturejournals.cz/publicFiles/10581.pdf.

[8] SEBEK, M., FALAT, L., KOVAC, F., PETRYSHYNETS, I., HORNAK, P. GIRMAN, V. (2017). The effects of laser surface hardening on microstructural characteristics and wear resistance of AISI H11 hot work tool steel. In: Arch. Metall. Mater. 62 (2017), 3, 1721-1726. [online]. 04.02.2020. Available from http://www.imim.pl/files/archiwum/Vol3_2017/43.pdf

DOI: 10.1515/amm-2017-0262.

[9] Kolektív autorov Materiály a ich správanie sa pri zváraní (2003). VÚZ - Priemyselný inštitút, Bratislava 355 s. ISBN 80-88734-10-X.

[10] NORMAN, T. E., SOLOMON, A., DOANE, D.V. (1959). Martensitic white irons for abrasion-resistant castings : Modern castings, v. 35, Apr., p. 104-118.

[11] BROŽEK, M. (2001). Mísení materiálů při navařování. In: Agrotech Nitra 2001. Nitra : SPU, 2001. s.46-50. ISBN 80-7137-874-7.

[12] BUCHELY, M.F., GUTIERREZ, J.C., LEON, L.M., TORO, A. (2005). The effect of microstructure on abrasive wear of hardfacing alloys. In: Wear, July 259(1):52-61 [online] 30.01.2020. Available from https://www.researchgate.net/publication/228509703_The_effect_of_microstructure_on_abrasive_wear_of_hardfacing_allos

DOI: 10.1016/j.wear.2005.03.002

[13] ZDRAVECKÁ, E. et al. (2012). Combined study of wear phenomena using wheel abrasion test. In: PRO-TECH-MA 2012:International scientific conference 2012, p. 456-463. - ISBN 97880-553-0950-7.

[14] KALINCOVÁ, D., ŤAVODOVÁ, M., LUPTÁČIKOVÁ, V. (2018). Application of the weld deposits on function surfaces of the forest machines components In: Manufacturing 
technology, Vol. 18, No. 3 p. 400-405. FME JEPU. Czech Republic

[15] KUSMIERCZAK, S., PESLOVA, F., NAPRSTKOVA, N. (2019) Influence of Heat Treatment Regime on Corrosion Resistance of Clad Aluminium Alloy In: Manufacturing Tecbnology, Vol. 19, No. 4, pp. 635-640. FME JEPU. Czech Republic

[16] MÜLLER, M., NOVÁK, P., CHOTĚBORSKÝ, R., HRABĚ, P. (2018) Reduction of Ploughshare Wear by Means of Carbide Overlay In: Manufacturing technology. Vol. 18, No. 1 pp. 72-78. FME JEPU. Czech Republic

[17] SUJOVÁ E., ČIERNA H., HNILICA R. (2016). Methodology proposal for identifying life-cycle costs (LCC) of mulchers of undesirable growth. In: MM Science Journal, No. November 2016, pp. 1166-1170. DOI:10.17973/MMSJ.2016_10_201693

[18] KALINCOVÁ D., ŤTAVODOVÁ M., HNILICOVÁ M., VEVERKOVÁ, D. (2016). Machinery for forest cultivation - increase of resistance to abrasive wear of the tool In $M M$ science journal. No. November, 2016, pp. 12691272. DOI: 10.17973/MMSJ.2016_11_201684
[19] GOST 23.208-79 Ensuring of wear resistance of products. Wear resistance testing of materials by friction against loosely fixed abrasive particles [online]. cit.20.01.2020. Available from https://www.internet-law.ru/gosts/gost/4066/

[20] VOTAVA, J., ČERNÝ, M., FILÍPEK, J. (2005). Influence of heat treatments on the abrasive wear. In: Acta univ. agric. et silvic. Mendel. Brun., 2005, LIII, No. 5, pp. 175-186.

[21] BALLA, J. (2003). Nánka o materiáloch. Nitra: SPU, 2003. 168 s. ISBN 80-8069-249-1

[22] NÁPRSTKOVÁ, N., ŠRAMHAUSER, K., CAIS, J., STANČEKOVÁ, D. (2018) Using of the Electron Microscope to Evaluate the Tool Wear for a Selected Cutting Insert In: Manufacturing Technology. Vol. 18, No. 4 pp. 635-640. FME JEPU. Czech Republic

[23] PEKOVIĆ, M., JENÍČEK, Š., RUBEŠOVÁ, K., VOREL, I., JIRKOVÁ, H. (2018) Welding of $42 \mathrm{SiCr}$ High-Strength Steel In: Manufacturing technology. Vol. 18, No. 1 pp. 84-89. FME JEPU. Czech Republic 